\title{
http://revistainvestigacionacademicasinfrontera.com
}

\section{LA REPARACIÓN DEL DAÑO, VÍCTIMAS DE ADOLESCENTES EN CONFLICTO CON LA LEY.}

\author{
María Teresa Gaxiola Sánchez ${ }^{1}$ \\ María del Rosario Molina González ${ }^{2}$ \\ María de Jesús Camargo Pacheco ${ }^{3}$
}

\section{Resumen}

A lo largo de la historia jurídica de nuestro país, entender el desarrollo intelectual de los jóvenes menores de edad para, con sustento en ello, definir con exactitud hasta qué punto son conscientes de sus acciones es un problema complejo, y esto nos ha llevado a que a lo largo de la historia se hayan creado diversos modelos de atención para los niños infractores. Ahora bien, ante las nuevas exigencias que, hacia nuestro país se han impuesto, por parte de organismos internacionales protectores de los derechos de los niños y las niñas, así como de los adolescentes que se ven inmersos en la comisión de conductas tipificadas como delitos, surgió la idea de crear un método garantista hacia éstos, que trascienda los límites del tutelarismo, por lo que en cuanto a este problema es que surge la reforma al artículo 18 Constitucional.

\footnotetext{
${ }^{1}$ Dra. María Teresa Gaxiola Sánchez, Profesora e Investigadora del Departamento de Ciencias Sociales, Universidad de Sonora, Unidad Regional Sur, Presidenta de la Academia de Derecho e Integrante del Cuerpo Académico Dogmática Jurídica y Proceso Educativo. Tendencias Actuales (UNISON-CA-165).

${ }^{2}$ Dra. María del Rosario Molina González, Doctora en Derecho, Profesora e Investigadora del Departamento de Ciencias Sociales, Universidad de Sonora, Unidad Regional Sur, Líder del Cuerpo Académico Dogmática Jurídica y Proceso Educativo. Tendencias Actuales (UNISON-CA-165).

3 Dra. María de Jesús Camargo Pacheco, Profesora e Investigadora del Departamento de Ciencias Sociales, Universidad de Sonora, Unidad Regional Sur, Integrante del Cuerpo Académico Dogmática Jurídica y Proceso Educativo. Tendencias Actuales (UNISON-CA-165).
} 


\title{
http://revistainvestigacionacademicasinfrontera.com
}

Las bases, y la trascendencia que representa la existencia del artículo 18 Constitucional, se sustenta, en que se observa una posición de proseguir que toma en cuenta las diferentes situaciones en especial de los menores de edad infractores, no solo desde el punto de vista de sus características biológicas o psicológicas, si no de manera primordial, en una consideración que se atiene, en todo momento, al respeto irrestricto de sus derechos y garantías. Este enfoque supone para el sistema de Justicia para Adolescentes una función social, que se encamina hacia la edificación de una convivencia en el marco de la legalidad, de lo que procede el reconocimiento de compromiso que los menores infractores tienen frente a la Ley Penal, como parte del proceso de vinculación por sus propios hechos, así como de la comprensión del carácter negativo que el delito tiene para su comunidad y, para sí mismo; por lo anterior, se consideran medidas aplicables a los menores infractores que lleven a cabo conductas tipificadas como delito, pero no como un castigo, sino como la necesidad de moldear en los menores pericia que formen ciudadanos responsables.

Palabras Claves: Reparación del Daño, Víctimas, Adolescentes, Daño, Ley.

\begin{abstract}
Throughout the legal history of our country, understanding the intellectual development of underage youth to, with support on it, define exactly how aware they are of their actions, is a complex problem, and this has led us that various models of care for child offenders have been created throughout history. However, in light of the new demands placed on our country by the international organizations that protect the rights of girls and boys, as well as of adolescents who engage in the commission of criminal behavior, arose the idea of creating a guaranteed method for these, which transcends the limits of tutelarismo, so in regard to this problem that arises the reform to Article 18 of the Constitution.
\end{abstract}




\section{http://revistainvestigacionacademicasinfrontera.com}

The bases, and the importance that the existence of Constitutional Article 18 represents, is sustained, that a continuation position is observed that takes into account the different situations, especially of juvenile offenders, not only from the point of view of their biological or psychological characteristics, if not in a primordial way, in a consideration that adheres, at all times, to the unrestricted respect of their rights and guarantees. This approach assumes a social function for the Justice System for Adolescents, which is aimed at building a coexistence within the framework of legality, from which comes the recognition of commitment that juvenile offenders have to the Criminal Law, as part of the bonding process by its own facts, as well as the understanding of the negative character that the crime has for its community and, for itself; for the foregoing, to the juvenile offenders who carry out behaviors typified as a crime, but not as punishment, but as the need to mold in the minors skills that form responsible citizens.

\section{Introducción}

En el presente trabajo se habla sobre la reparación del daño a víctimas de adolescentes en conflicto con la Ley, se realiza una comparativa sobre los delitos más comunes cometidos por adolescentes, los cuales son robo, violación, homicidio y abusos deshonestos, según lo que la víctima solicita en cuanto a la reparación del daño causado al momento de cometer el ilícito, podemos darnos cuenta que es una cifra elevada de víctimas que solicitan que se les pague en su totalidad el daño causado ya sea en sus bienes o en su persona o bien el daño psicológico que pudiera ocasionarle el verse envuelta en un hecho delictivo, la víctima en su mayoría de los casos pide que se le castigue conforme a derecho al adolescente imputado, y coinciden que no desean otorgarles el perdón para que puedan salir en libertad, aunque esto no define la situación jurídica, si les afecta al adolescente. 
Julio- Diciembre 2017)

Año 10.

Revista de Investigación

Núm. 26

Académica sin Frontera

ISSN: 2007-8870

\section{http://revistainvestigacionacademicasinfrontera.com}

\section{Material y Método}

Se analizó las sentencias dictadas en el Juzgado de Primera Instancia Especializado en Justicia para Adolescentes del Segundo Circuito con Cabecera en Cócorit, Sonora, en donde se realizó una síntesis de una serie de expedientes en cuanto a los delitos más comunes que se procesan en este Tribunal, los cuales son: Violación, Robo Agravado, Homicidio y Abusos Deshonestos, mismos que considero solamente los puntos resolutivos de las mismas, enfocándome en la reparación del daño a la víctima de los adolescentes en conflicto con la Ley.

Cabe señalar que se omiten generales de los adolescentes, en las sentencias dictadas en el Juzgado de Primera Instancia Especializado en Justicia para Adolescentes, dado como ya expliqué en capítulos anteriores de mi trabajo de investigación, en el artículo 9 fracción XV de la Ley que establece el Sistema Integral de Justicia para Adolescentes del Estado de Sonora ${ }^{4}$ así como demás relativos donde no pueden mostrarse nombres ni identidades de los adolescentes.

A continuación, relataré los puntos resolutivos de diversas sentencias, en cuanto a la medida que dicto el Juez relativa a la reparación del daño a la víctima de la conducta desplegada por el adolescente ${ }^{5}$.

\footnotetext{
${ }^{4}$ Ley 252. Que establece el sistema integral de justicia para adolescentes del Estado de Sonora.

${ }^{5}$ Información obtenida del archivo del juzgado de adolescentes.
} 
Julio- Diciembre 2017)

Año 10.

Revista de Investigación

Núm. 26

Académica sin Frontera

ISSN: 2007-8870

\section{http://revistainvestigacionacademicasinfrontera.com}

\subsection{Violación}

En los casos de violación con lleva entre otras medidas al pago de la reparación del daño tanto moral como material ya que esta conducta desplegada por un adolescente, en la mayoría de sus casos genera un daño moral, ya que al momento de realizar el hecho delictivo, el adolescente genera cierta violencia tanto física como verbal, en algunos casos son menores impúber lo que significa que no tienen suficiente madurez para comprender el hecho, o en otros el menor padece de sus facultades mentales, a continuación relatare los puntos resolutivos que dicto el Juez de Primera Instancia Especializado en Justicia para Adolescentes en donde sentencio a un adolescente a la reparación del daño moral y material ya que la menor requirió terapias psicológicas por el daño causado a raíz de que se llevó a cabo el delito, así mismo lo condeno al pago de la reparación del daño material donde el C. Juez promedia el grado de pena, que sería en baja, media y máxima a partir de esos saca el aproche para imponer el pago según el equivalente a salarios mínimos vigentes en el estado de Sonora en la época de la comisión del delito, donde se realiza el pago por medio del representante legal.

En la siguiente sentencia el Juez en turno dicto sentencia de responsabilidad al adolescente Jesús Gómez en la conducta tipificada como delito de violación agravada (por haberla sorprendido en lugar despoblado). A lo que se le impusieron las siguientes medidas en cuanto a la reparación del daño:

Se le impuso la obligación de pagar el equivalente a cuatrocientos seis días de salario mínimo general vigente en la capital del estado, en la época de la comisión de la conducta, equivalente a $\$ 28,460.60$, a razón de $\$ 70.10$ por concepto de reparación del daño moral, a favor de la menor ofendida, por conducto de su representante legal. 


\section{http://revistainvestigacionacademicasinfrontera.com}

De igual forma se le impuso la reparación del daño material a favor de la menor ofendida por conducto de su representante legal, a quien el adolescente deberá pagar la cantidad de $\$ 14,400.00$ que es el costo de la terapia psicológica que requerirá dicha ofendida, lo anterior por la vía legal para ello y por conducto de su representante legal.

De la misma forma en esta sentencia se dictamina la responsabilidad al adolescente y en forma justa y equitativa se le impusieron las siguientes medidas en cuanto a la reparación del daño refiere:

Reparación del daño a la víctima en la cual se le impone pagar a la víctima el equivalente a trescientos días de salario mínimo general vigente en la capital del estado de Sonora, en la época de la comisión de la conducta, consistentes en \$21,912.00 a razón de $\$ 73.04$ diarios, por concepto de reparación del daño moral, a favor del menor ofendido, por conducto de su legítimo representante, y por las vías legales para ello.

Por otra parte, se le impone al adolescente la mediad de pago de reparación del daño material, a favor del adolescente menor ofendido a quien el adolescente de mérito deberá pagar la cantidad de $\$ 12,720.00$.

De igual manera en esta sentencia se le condeno al pago de la reparación del daño al ofendido u ofendida, en la cual tiene la obligación de pagar cuatrocientos cincuenta y siete días de salario mínimo general vigente en la capital del estado de sonora en la época que se llevó a cabo la conducta, equivalente a \$29,595.32 a razón de \$64.76 diarios por concepto de reparación del daño moral, a favor de la menor ofendida, por conducto de su representación legal. 


\section{http://revistainvestigacionacademicasinfrontera.com}

En esta sentencia cabe destacar que no se condenó al pago de la reparación del daño material, por lo que no hubo elementos suficientes para comprobar que hubiera dichos gastos, o sé que hubiera dicho daño.

\subsection{Homicidio}

El delito de homicidio conlleva, entre otras medidas, a la reparación del daño, aun y cuando el juicio de reproche formulado sea a título de culpa; dada la naturaleza de los daños materiales como morales causados por esa acción delictiva, se da nacimiento a dos acciones, una del orden penal y la otra civil; sin embargo, al momento de intervenir las autoridades penales, las acciones civiles en reparación del daño son absorbidas por la legislación penal; existen algunos casos en que la reparación debe ser pagada por los padres y/o tutores del adolescente infractor, y otros en los que la obligación de pago pasa a terceras personas, en cuyo supuesto corresponde intentar la acción de pago a la parte ofendida.

Es evidente que existe una diferencia entre la reparación del daño exigible al adolescente y la responsabilidad civil proveniente de delito que se exige a un tercero, ya sea vía civil o a través del incidente mencionado; no obstante, ello es inconcuso que el monto al que debe ascender la indemnización por concepto de reparación del daño debe ser el mismo en ambos casos.

Por todo lo anterior, no existe violación alguna de garantías en el hecho de que el juzgador, para cuantificar el monto al que asciende dicha reparación, se fundamente en disposiciones extrañas a la legislación penal, siempre y cuando a ellas recurra sólo para encontrar el criterio de esa cuantificación, razón por la cual es correcto que al no existir en la causa penal elementos probatorios que le permitan determinar la cuantía de los daños causados, se aplique lo dispuesto por el artículo 1915 del Código sustantivo en materia civil, 


\section{http://revistainvestigacionacademicasinfrontera.com}

en virtud de que únicamente debe existir un criterio eficaz para establecer adecuadamente el monto de la indemnización, y que es el establecido por voluntad del legislador en el ordenamiento civil, ya que en la legislación penal no existe precepto alguno que establezca las reglas a seguir en este supuesto.

En esta sentencia dictada en el Juzgado de primera Instancia Especializado en Justicia para Adolescentes acreditándose la conducta tipificada como delito de Homicidio Calificado se comprobó la plena responsabilidad de los adolescentes de mérito de los cuales se omiten sus generales, en consecuencia, se les dictaron las siguientes medidas, Internamiento por cinco años y la reparación del daño a la madre del pasivo fallecido por la cantidad de \$23,760. 00 lo cual se deberán pagar en forma mancomunada, esto como resultado de gastos funerarios y gastos atientes al ilícito que cometieron los menores infractores.

Por otra parte, se les impuso a los adolescentes pagar en forma mancomunada por concepto de reparación del daño moral la cantidad de setecientos cincuenta días de salario mínimo general vigente en la capital del Estado, en la época de los hechos, lo cual equivale a la cantidad de $\$ 52,575.00$ a favor de la madre del adolescente occiso.

En la siguiente sentencia se condena al pago de la reparación del daño pero se deja a salvo los derechos; se dicta sentencia de responsabilidad a los adolescentes y en forma justa y equitativa se les impusieron las siguientes medidas:

Internamiento por siete años, reparación del daño a los ofendidos, en base a lo solicitado por la fiscalía adscrita, atendiendo a lo previsto en el artículo 15 de la Ley que Establece el Sistema Integral de Justicia para Adolescentes del Estado de Sonora, en el artículo 29 bis y 31 bis del Código Penal para el Estado de Sonora, para la 


\section{http://revistainvestigacionacademicasinfrontera.com}

cuantificación del daño moral, a las reglas de la individualización de las medidas, al grado de responsabilidad en que este Juzgador ubico a los adolescentes y a su capacidad económica, se impone a los adolescentes... la obligación de pagar mancomunadamente, a favor de la o las personas que a derecho corresponda su cobro, respecto a ambos ofendidos, la cantidad de $\$ 70,100.00$, equivalente a un mil días de salario mínimo general vigente en la capital del Estado, al momento de la comisión de los presentes hechos, a razón de $\$ 70.10$ diarios, por concepto de reparación del daño moral, por la conducta tipificada como delito de homicidio, toda vez que nos encontramos ante una conducta en la cual se presume el daño moral.

De igual forma, con fundamento en los articulo 115 y 116 de la Ley que establece el Sistema Integral de Justicia para Adolescentes del Estado de Sonora, se impone a los dos adolescente la medida de reparación del daño material, a favor del abuelo del occiso a quien los adolescentes deberán pagar de manera mancomunada la cantidad de \$7,802.00 por concepto de gastos funerarios, así mismo se les deberá pagar de manera mancomunada a Rosa Leyva, quien fue la persona que cubrió los gastos funerales del otro occiso, la cantidad de $\$ 7,500.00$, por concepto de gastos funerarios.

También en esta sentencia en cuanto al expediente número 175/2014 se dictó sentencia responsabilidad por la conducta tipificada como delito de culposo con resultado de homicidio. Se le impusieron las siguientes medidas en cuanto a la reparación del daño a la víctima en el punto resolutivo tercero apartado e):

En base a lo solicitado por la fiscalía adscrita, atendiendo a lo previsto en el artículo 115 de la Ley que establece el sistema Integral de Justicia para Adolescentes del Estado de Sonora, y en los artículos 29 bis y 31 bis del Código Penal para el Estado de Sonora, para la cuantificación del daño moral, a las reglas de la individualización de las medidas, al grado 
Julio- Diciembre 2017)

Año 10.

Revista de Investigación

Núm. 26

Académica sin Frontera

ISSN: 2007-8870

\section{http://revistainvestigacionacademicasinfrontera.com}

de responsabilidad en que este Juzgador ubico al adolescente y a su capacidad económica, se impone al adolescente...la obligación de pagar, a favor de los C.C. José Pereza y María López en su carácter de padres de la pasivo, así como de la menor Ana Gómez, hija de la ahora occisa, la cantidad de $\$ 26,916.00$, equivalentes a cuatrocientos días de salario mínimo general vigente en la capital del Estado, al momento de la comisión de los presentes hechos, a razón de $\$ 67.29$ diarios por concepto de reparación del daño moral, por la conducta tipificada como homicidio por culpa perpetrado en agravio de Ana Pereza López, en virtud de que nos encontramos en presencia de un delito el cual la Ley presume que se actualiza el daño moral, por tanto, y al haberse así solicitado por la Representante Social en su pliego de acusación, es procedente imponer esta condena, tomando en cuenta además el numeral 31 bis, segundo párrafo del Código Penal para el Estado de Sonora, establece que en los casos en que la Ley presuma daño moral, pero se omita acreditar, se podrá imponer, a juicio del juez, de cincuenta a mil días de salario mínimo, en atención a la individualización de sanciones y a la capacidad económica del obligado a pagarla.

En cuanto a la reparación del daño material se impone al adolescente de mérito el pago sin determinación de cantidad liquida, a favor de los padres de la occisa y su menos hija, dejándole a estos a salvo los derechos para que en la vía incidental, en términos del citado artículo 116 de la Ley que establece el sistema integral de justicia para adolescentes del estado de sonora, en relación con el artículo 444-A y demás relativos del código de procedimientos penales para el estado de sonora, acrediten a cuánto ascienden los daños materiales causados por el adolescente al momento de consumar la conducta en su perjuicio, ello en razón de que no se allego al sumario prueba idónea con la cual se cuantifique dicho daño. 
Julio- Diciembre 2017)

Año 10.

Revista de Investigación

Núm. 26

Académica sin Frontera

ISSN: 2007-8870

\section{http://revistainvestigacionacademicasinfrontera.com}

\subsection{Robo agravado}

El delito de robo es de los más comunes, si no es que él se presenta frecuentemente en adolescente, me atrevería a decir que en porcentaje esta conducta ocuparía un $80 \%$ del $100 \%$ de los expedientes que están en trámite en ese Juzgado, entonces a continuación analizare las sentencias denotando de igual forma cómo es que se impone el pago a la reparación del daño en sentencia.

En esta sentencia se comprobó plenamente la conducta tipificada como delito de robo de noche, en donde el Juez impuso medidas de externamiento en las cuales no atribuyo al adolescente imputado al pago de la reparación del daño tanto moral como material, ya que en diligencias anteriores el adolescente de mérito realizo el pago a la reparación del daño, así en sentencia no se solicitó por la fiscalía al pago de la misma y se absolvió de esa medida.

Por otra parte, en la sentencia dictada por el C. Juez, se encontró la plena responsabilidad del adolescente y en forma justa y equitativa impuso las siguientes medidas; Medidas de externamiento dado que en autos anteriores se llevó a cabo la diligencia de reparación del daño, donde se reparó cualquier daño o perjuicio a la víctima de la conducta tipificada como delito.

De igual forma en esta sentencia se impusieron las siguientes medidas en lo que a reparación del daño a la víctima refiere; Previstos en el artículo 115 y 116 de la Ley que establece el sistema integral de justicia para adolescentes del estado de sonora, y conforme a los cuales se impone al adolescente, la medida de reparación del daño material sin determinación de cantidad liquida, a favor del ofendido, dejándole a salvo los derechos para que en vía incidental, en término del artículo 116 de la mencionada ley, en relación al artículo 444-A y demás relativos del código de procedimientos penales para el Estado de Sonora, 
Año 10.

Revista de Investigación

Núm. 26

ISSN: 2007-8870

\section{http://revistainvestigacionacademicasinfrontera.com}

acredite a cuánto ascienden los daños materiales causados por el adolescente al momento de consumar la conducta en su perjuicio, ello en razón de que no se allego al sumario prueba idónea con la cual se cuantifique el daño.

\section{Resultados}

Graficas clasificadas por los delitos más comunes en el Tribunal de adolescentes en Cocorit, Sonora, estadística basada en los expedientes con sentencia impuesta en el periodo de enero 2015 a diciembre de 2015, dando como resulta de 98 expedientes analizados, de los cuales sondee en la diligencia de reparación del daño que se da al inicio del proceso y en la sentencia definitiva como se impuso la medida de reparación del daño a la víctima del adolescente en conflicto con la Ley.

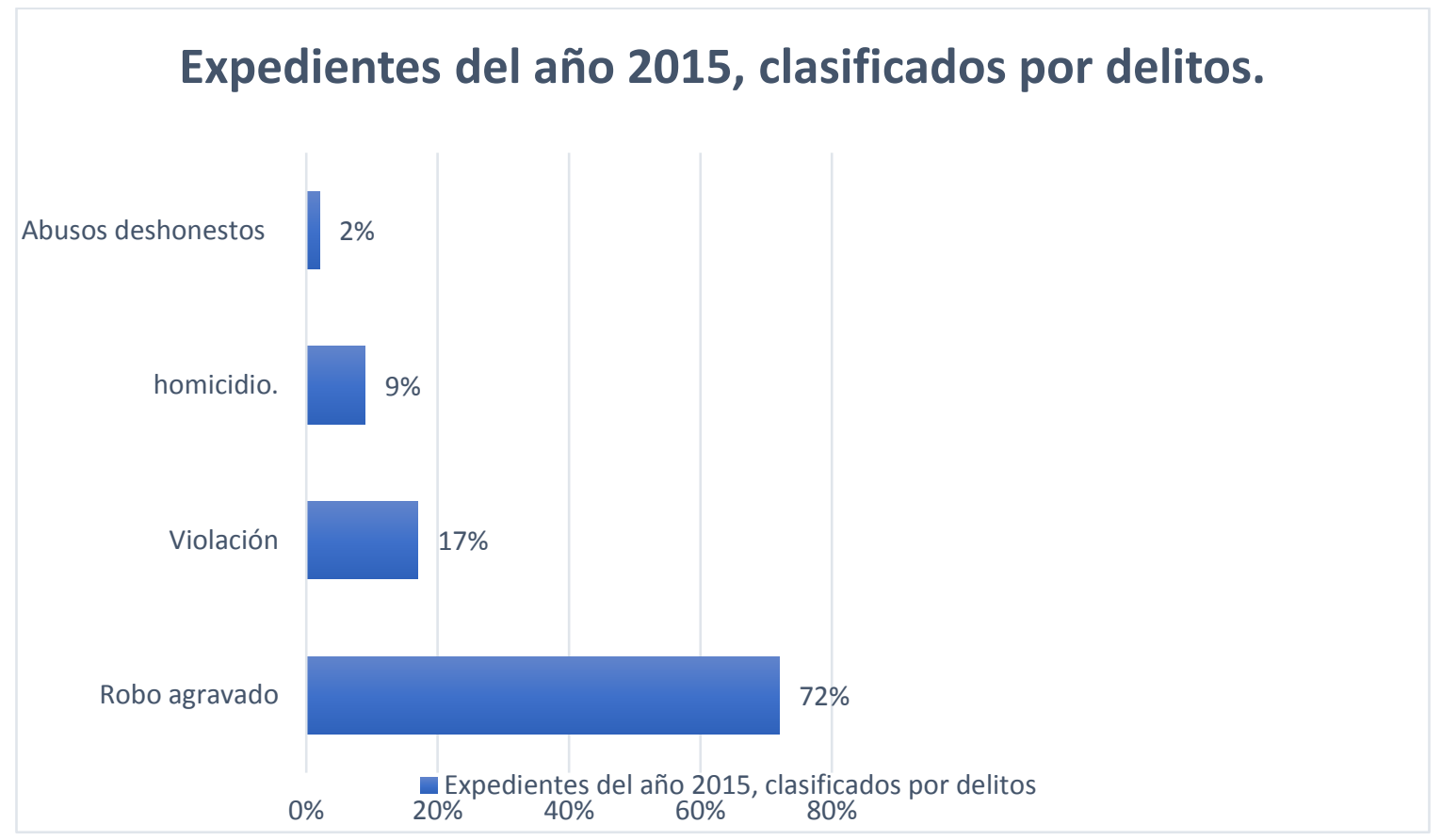




\section{http://revistainvestigacionacademicasinfrontera.com}

Grafica 1. Es notorio que el delito con más incidencia es el de robo, seguidamente el de violación, homicidio y por último el delito de abusos deshonestos, en las gráficas siguientes analizare varios puntos de la reparación del daño, desde la comparecencia del ofendido o víctima del delito, en cuanto a que solicita en la diligencia, hasta el punto de que medida el juez impone al adolescente en sentencia.

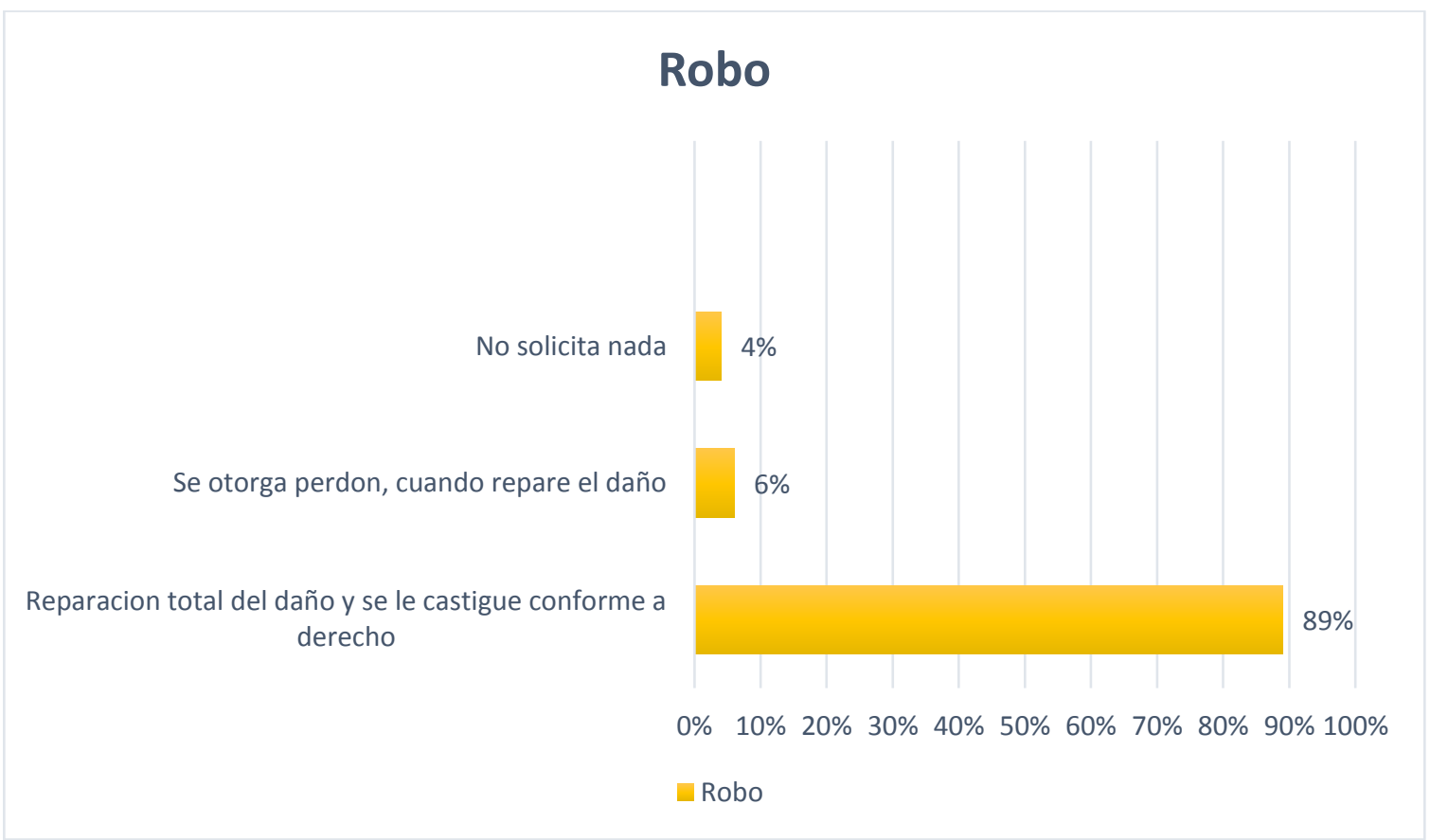

Grafica 2. En el presente gráfico, indago en el delito de Robo, el más común en ese H. tribunal, del cual lo más común es que la víctima pide que se le resarza el daño ocasionado a raíz de la conducta desplegada por el adolescente, y en cuanto al menor que pague conforme a derecho. En segundo lugar con el $6 \%$ la victima u ofendido pide que si el adolescente sus padres y/o tutores le pagan el daño ocasionado le otorgaran el perdón, y por ultimo lo menos 


\section{http://revistainvestigacionacademicasinfrontera.com}

común es que pida la víctima no pida nada, son casos muy poco comunes pero existen, ya que la víctima por empatía, miedo o falta de medios económicos para estar asistiendo al juzgado desiste de todo y solo desea que el proceso termine y no se le moleste más al respecto.

Cabe aclarar que los presentes datos, fueron obtenidos de los expedientes del año antes mencionado, en cuanto a la comparecencia de los ofendidos, que se lleva a cabo al inicio del proceso, antes de la resolución constitucional.

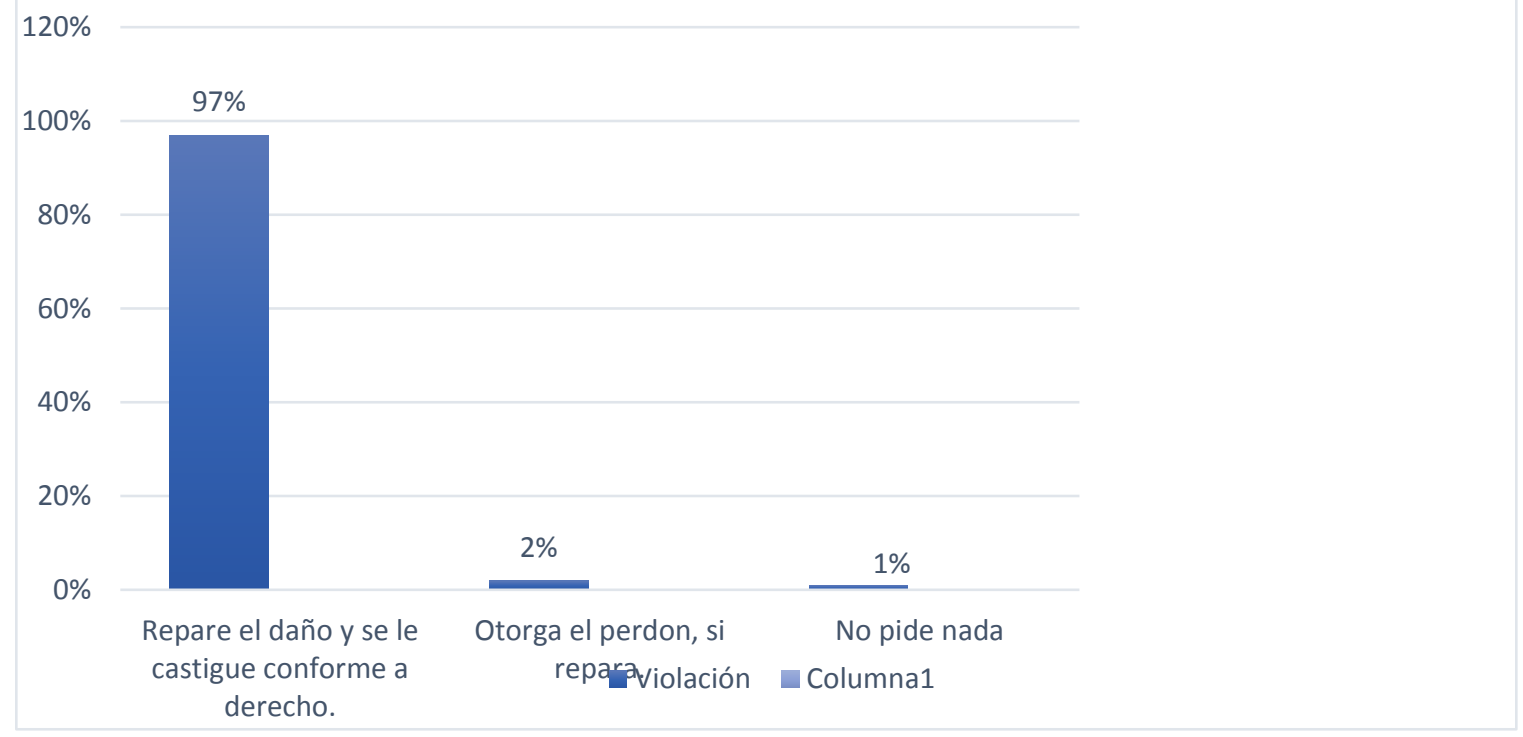

Grafica 3. En el presente gráfico, que se examina el delito de Violación, observamos que la mayoría de las victimas piden que se les repare el daño, ya que en estos casos el daño moral es el más afectado, siendo que la víctima queda muy dañada por loa traumático del hecho, 
Núm. 26

ISSN: 2007-8870

\section{http://revistainvestigacionacademicasinfrontera.com}

las posibilidades de que se otorgue el perdón en estos casos es casi nula y en el caso de que no soliciten nada, también lo es. Es una conducta muy fuerte, se daña bastante a la víctima, en algunos casos existe violencia física debido a que la víctima opone resistencia comúnmente lo que conlleva a un forcejeo donde la o el ofendido en la mayoría de casos es menor en edad, complexión y madurez que el adolescente que comete el delito por lo que la violencia física puede ser un elemento factible en la conducta desplegada.

\section{Homicidio}

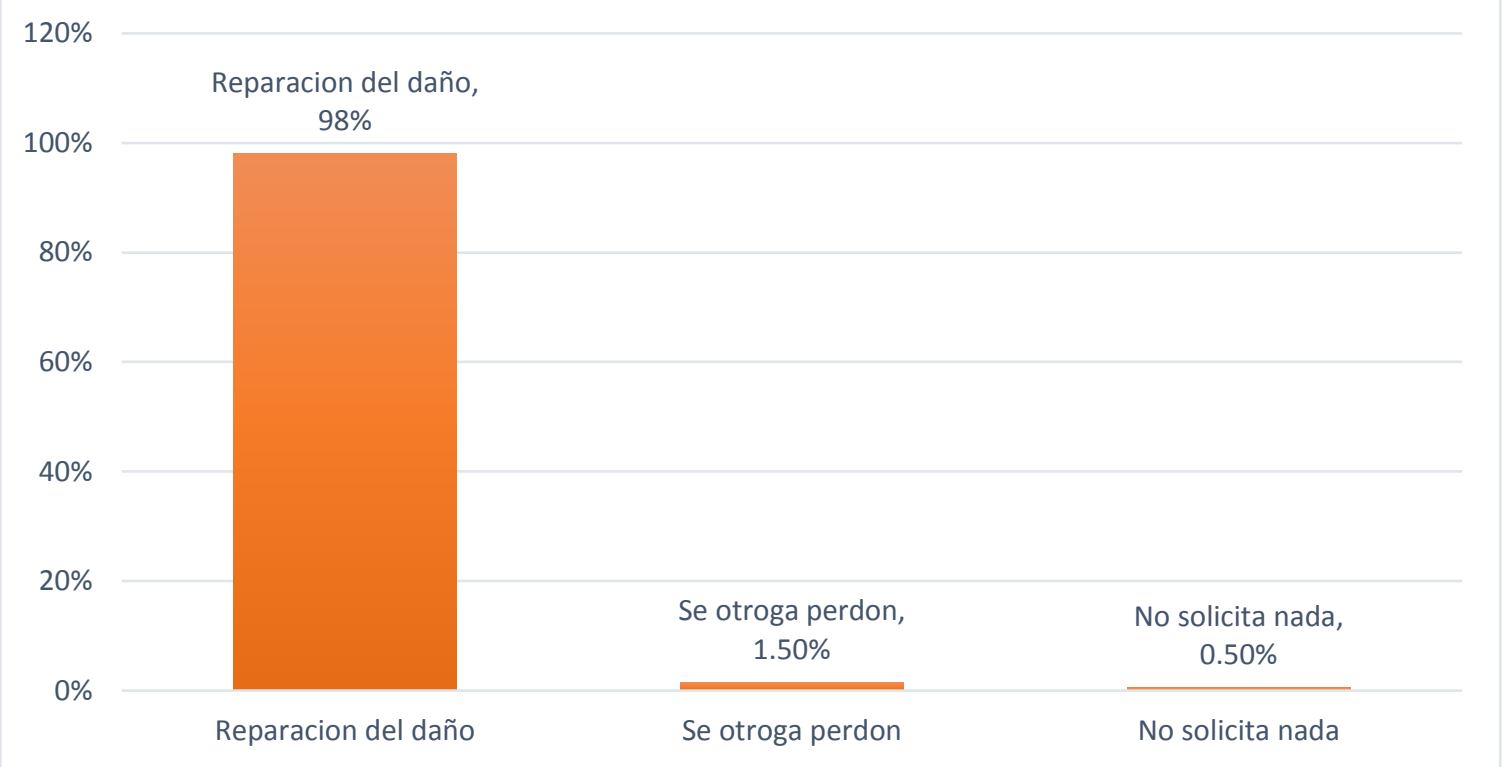

Gráfico 4. El delito de homicidio, es muy fuerte para los familiares del ofendido occiso, la mayoría de los casos las personas cercanas al difunto, solo piden que se les paguen los gastos 
Año 10.

Revista de Investigación

Núm. 26

ISSN: 2007-8870

\section{http://revistainvestigacionacademicasinfrontera.com}

funerarios, en mi experiencia me ha tocado seguir casos de homicidios en el Juzgado de menores, los familiares se encuentran muy afectados por lo traumático de la situación que están viviendo, algunas personas dependían de sus hijos fallecidos, otros tenían hijos pequeños y quedan completamente desamparados si una figura masculina que los proteja; he observado madres de menores que fallecen por riñas que no les interesa que se les repare mas que los gastos funerarias a lo que manifiestan que aunque se les repare el daño moral, nada les regresara a su hijo fallecido, hay casos muy fuertes.

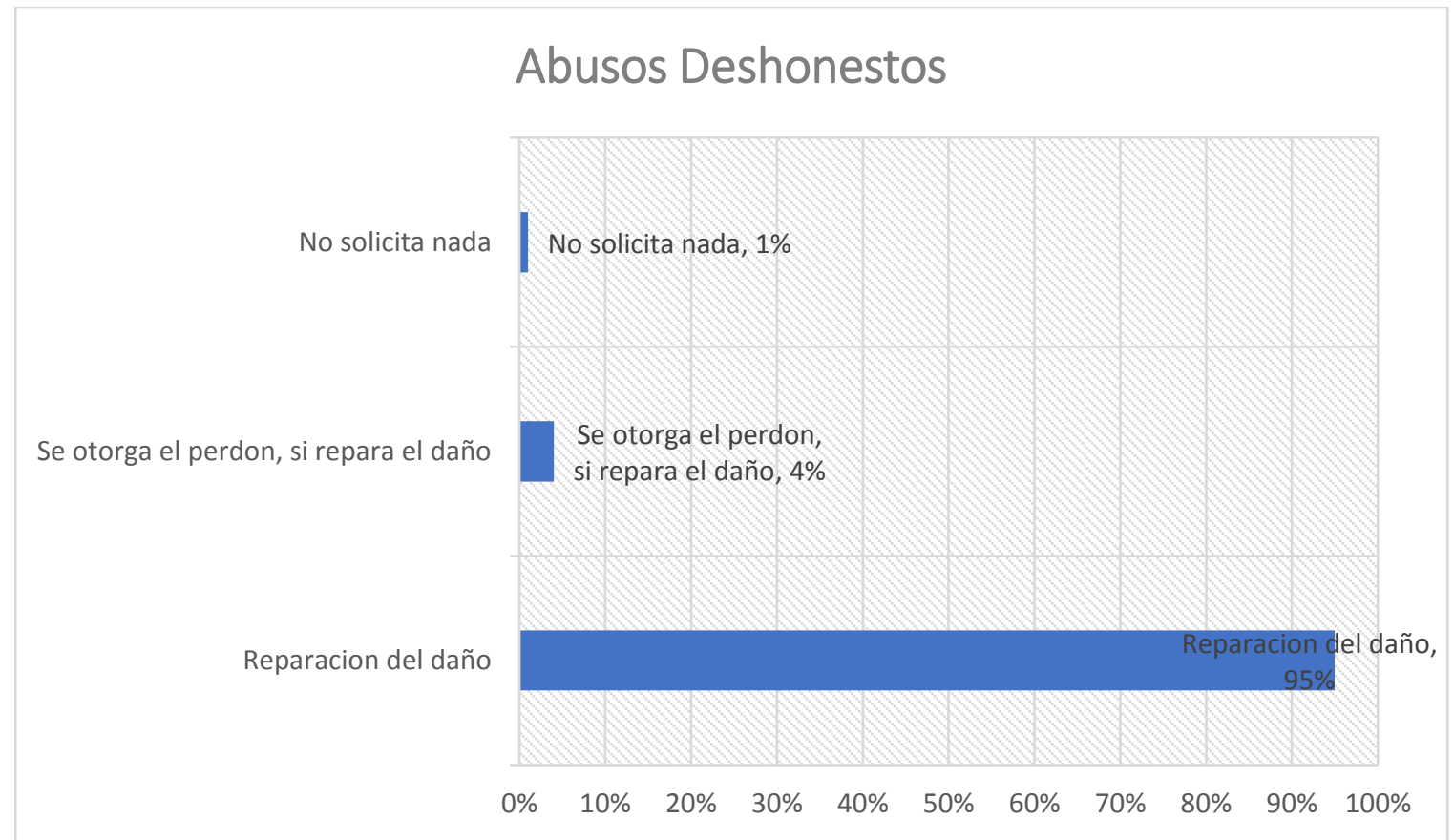


Julio- Diciembre 2017)

Año 10.

Revista de Investigación

Núm. 26

Académica sin Frontera

ISSN: 2007-8870

\section{http://revistainvestigacionacademicasinfrontera.com}

Gráfico 5. En la presente gráfica se muestra el delito de abusos deshonestos, que igual es un delito que al igual que por el grado de trauma de la conducta desplegada hacia la víctima, misma que en el $95 \%$ de los casos pide que se le repare el daño causado, solo el $4 \%$ otorga el perdón si se le repara el daño, y el 1\% no solicita nada, la posibilidad de no solicitar nada es casi nula, cuando son menores ofendidos en algunos casos los padres no quieren exponer a su menor hijo o hija a un juicio y a tener que asistir a diligencia donde probablemente tenga que ver al adolescente inculpado, son raros los casos que esto pasa, por como se muestra en la gráfica la mayoría de las personas quiere se le castigue conforme a derecho y resarza el daño que causo, en este caso el moral es el más lesionado.

En los siguientes gráficos, se ofrece una muestra, ya en sentencia como se impone la medida de reparación del daño a la víctima de un adolescente en conflicto con la Ley, hice divide por tres segmentos, la primera en cuanto a que porcentaje de sentencias se les impone el daño material y moral, en qué porcentaje solo se impuso solo una y en cuantas se dejaron a salvo los derechos para hacerlos valer por la vía incidental. 


\section{http://revistainvestigacionacademicasinfrontera.com}

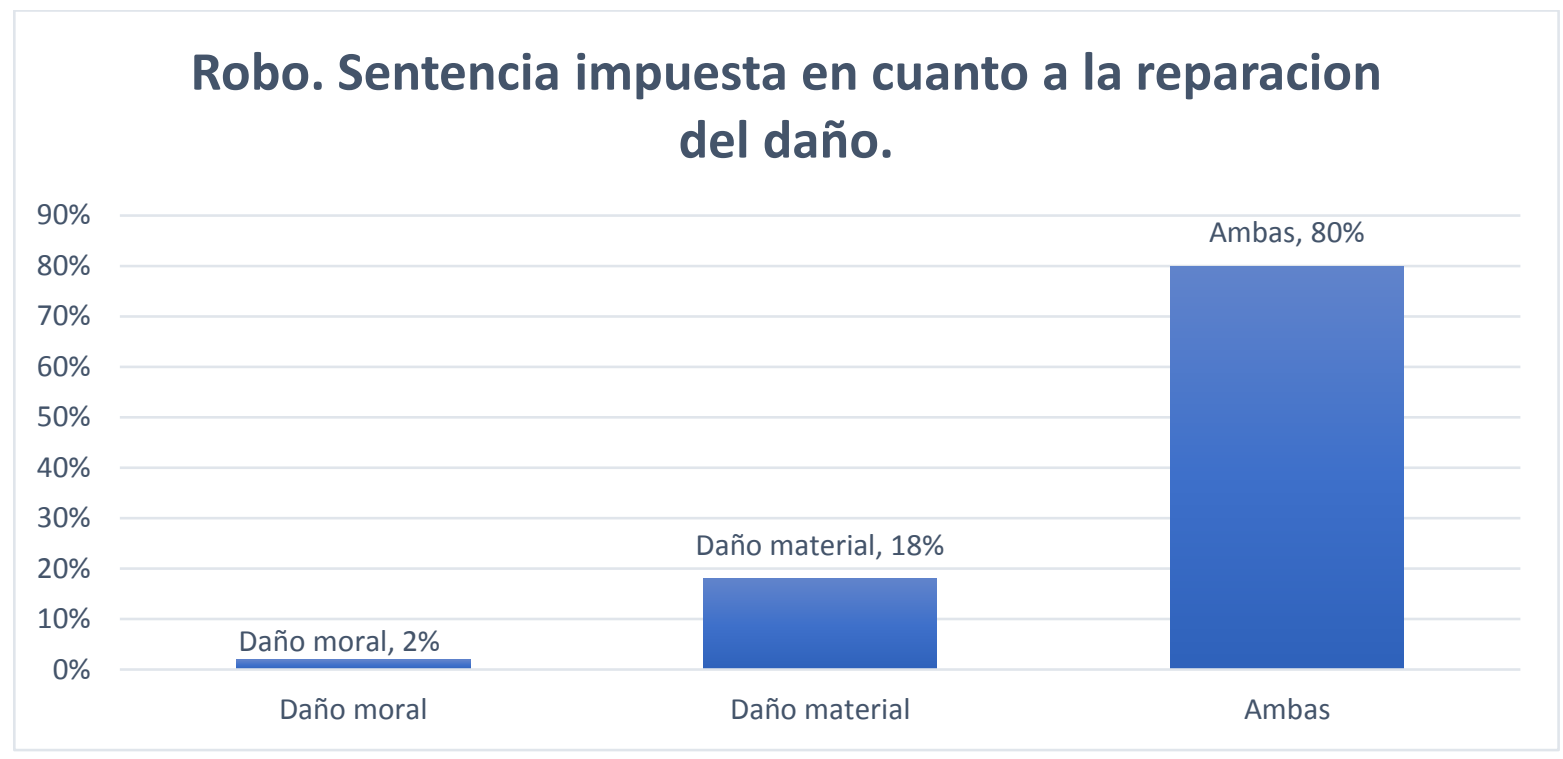

Gráfico 6. En cuanto a este gráfico, se examinaron las sentencias impuesta por delito de robo agravado, la cuales arrojaron que en el $80 \%$ de las sentencias se le impone la medida de reparación del daño material y moral al adolescente, en un $18 \%$ se le impone solamente el daño material causado a la víctima en la comisión del delito, y en solo un $2 \%$ se le impone solamente el daño moral, esto debido a que en el delito de robo, se entiende que es el desapoderamiento de algún bien, por lo tanto al entrar a robar a una casa y apoderarse de artículos que hay en la misma para entrar a la casa habitación, tendría que forcejear la puerta o ventana dado el caso, entonces ahí hay un daño material, y si la casa está habitada al momento de introducirse ahí se genera un daño moral, por consecuencia se están dañando tanto materialmente como moralmente a la víctima y el juez decide imponer ambas medidas.

Por otra parte, en la siguiente grafica se hace un muestreo de las sentencias en delito de robo, en cuanto a que porcentaje de sentencias se determina cantidad al momento de imponer la 
Núm. 26

ISSN: 2007-8870

\section{http://revistainvestigacionacademicasinfrontera.com}

medida de reparación del daño y en cuantas se dejan a salvo los derechos para así hacerlos valer por la vía incidental en el momento que la víctima lo desee.

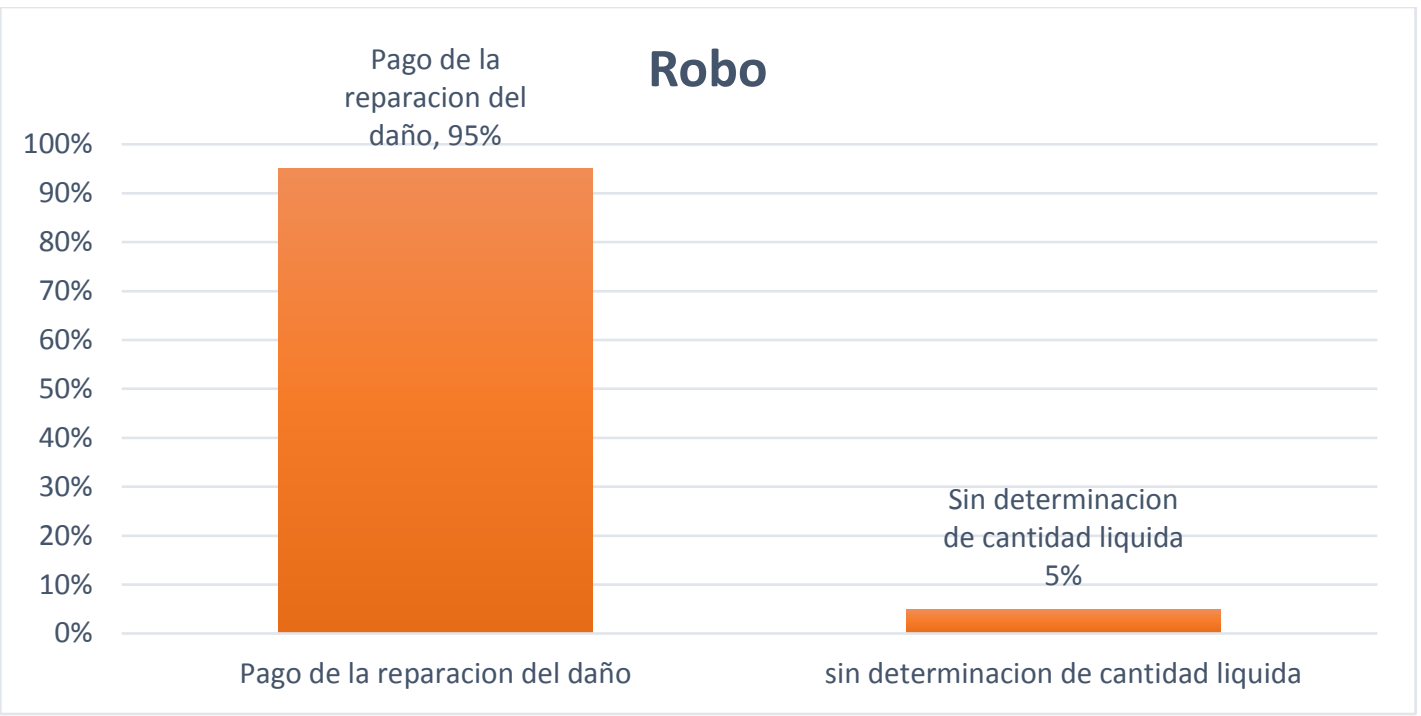

Gráfico 7. En el presente gráfico podemos apreciar que en sentencia el juez impone el pago de la reparación del daño determinando la cantidad que el adolescente deberá pagar a la víctima $\mathrm{u}$ ofendida, tomando en cuenta notas y facturas ratificadas, que la víctima haya presentado ante el Ministerio Público adscrito al H. Tribunal de adolescentes, las cuales en el momento oportuno se dieron por admitidas en ese Tribunal.

En cuanto al delito de violación, se impusieron las siguientes medidas en sentencia en cuanto a la reparación del daño, tomando en cuenta si hubo reparación del daño moral, material o ambas. 
Núm. 26

ISSN: 2007-8870

\section{http://revistainvestigacionacademicasinfrontera.com}

\section{Violación en sentencia impuesta.}

$80 \%$

$70 \%$

$60 \%$

$50 \%$

$40 \%$

$30 \%$

$20 \%$

$10 \%$

$0 \%$
Daño moral, 20\%

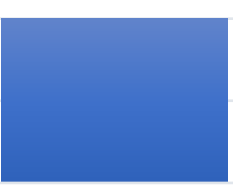

Daño moral
Daño material, 5\%

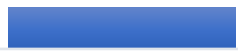

Daño material
Ambas, 75\%

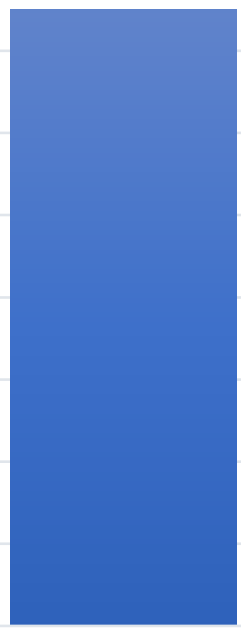

Ambas

Gráfico 8. En razón del delito de violación observamos en la gráfica que el $75 \%$ de expedientes sondeados se muestra que se impone la reparación del daño moral y material a la víctima, mientras que un $20 \%$ solo se le impone el daño moral y con un $5 \%$ el daño material, lo que demuestra que en este delito la víctima es casi en una su totalidad de daño subsanado. 


\section{http://revistainvestigacionacademicasinfrontera.com}

\section{Violación}

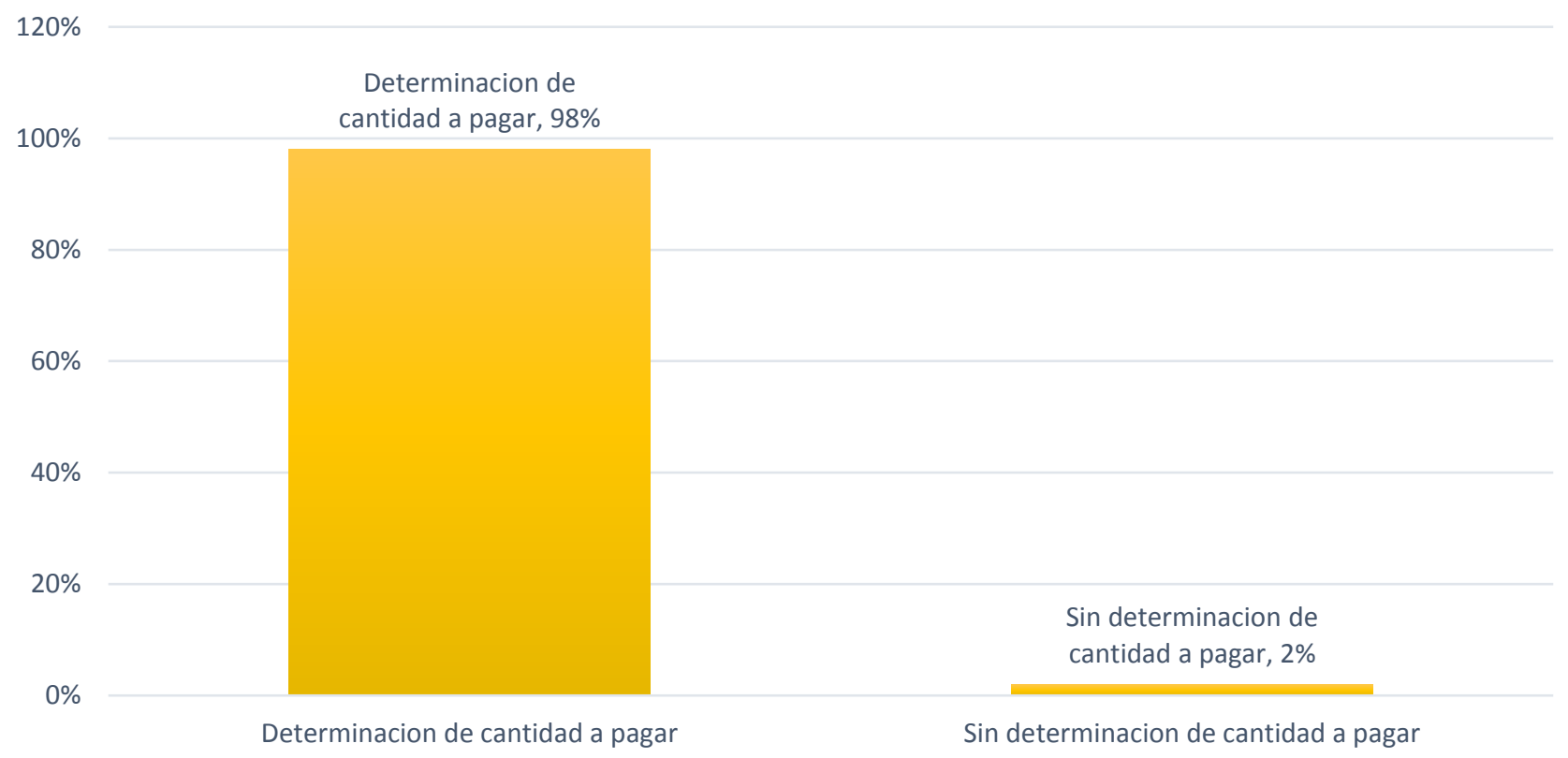

Gráfico 9. En el presente Gráfico en cuanto al delito de violación, claramente observamos que en sentencia es común que se determine la cantidad a pagar, ya que en estos casos la victima tiene que acudir a COPAVID para que la valore un psicólogo y determine qué cantidad de terapias psicológicas requerirá, en base a eso se saca un valor estimado por sesión y el costo de la misma, siendo este un total de las terapias a lo que el juez impone que se le paguen las terapias que necesitara la víctima, los casos en los que no se determina puede ser que la víctima no haya querido acercarse al Juzgado o al ministerio público para ver la manera de que se le subsanara el daño ocasionado. 
Núm. 26

ISSN: 2007-8870

\section{http://revistainvestigacionacademicasinfrontera.com}

\section{Homicidio}

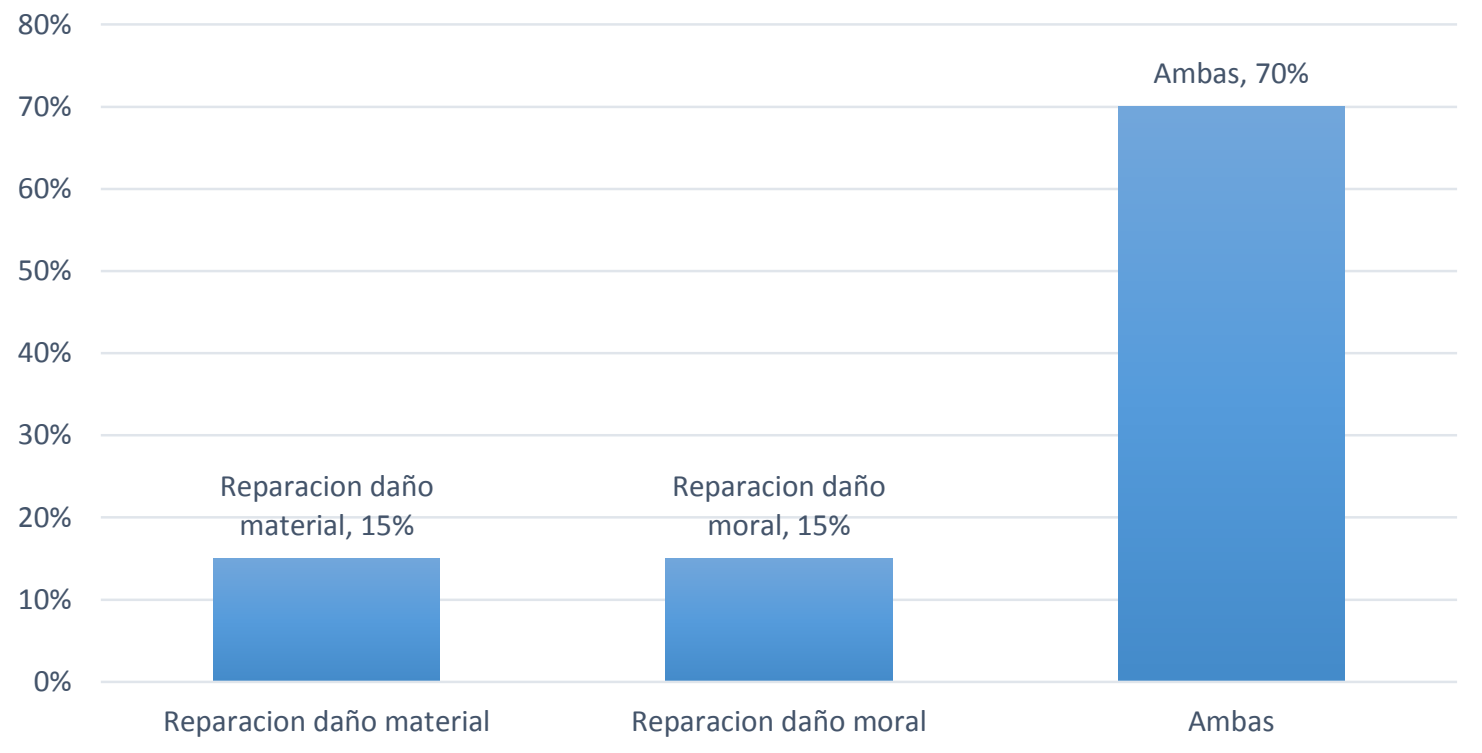

Gráfico 10. En cuanto a la reparación del daño material y moral, en sentencia impuesta, en la mayoría de los expedientes se impuso la medida del pago de ambas, mientras la reparación del daño material fue de un $15 \%$ en el total de expedientes sondeados y el daño moral igual con un $15 \%$, lo que nos muestra que en el delito de homicidio se daña tanto material como moralmente a la víctima en estos casos a los familiares del occiso. 


\section{http://revistainvestigacionacademicasinfrontera.com}

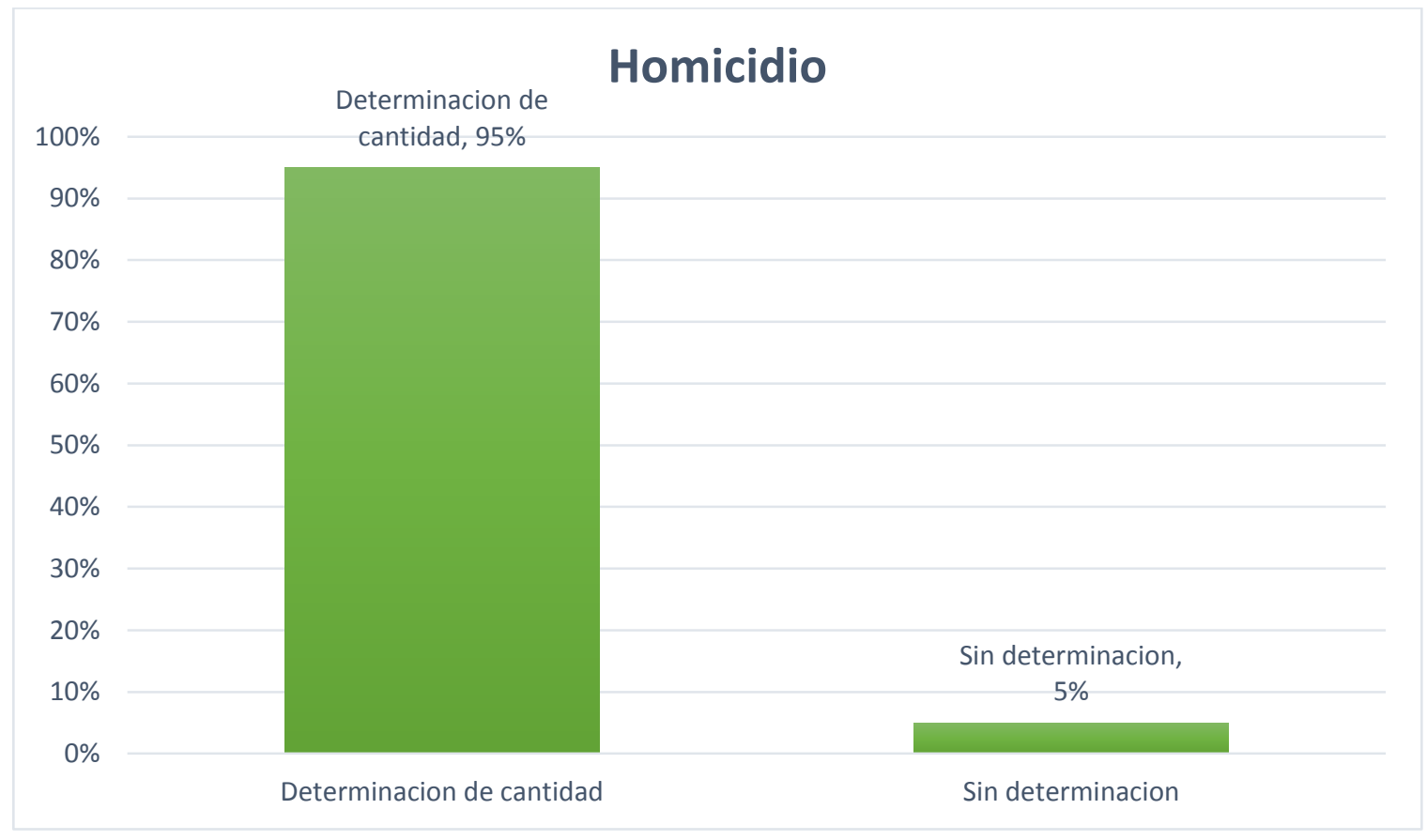

Gráfico 11. En el gráfico nos muestra como en sentencia impuesta al adolescente se le impone la medida de pago de la reparación del daño, pero en un 95\% de expedientes analizados arrojo que en su mayoría se determina cantidad a pagar a los familiares del occiso, ya sea por que generaron gastos médicos, funerarios, etc. Mientras que en un 5\% de los expedientes examinados no se determina cantidad a pagar a las víctimas.

En las siguientes gráficas, se analizó el delito de abusos deshonestos en el cual también hice un sondeo igual que en los anteriores gráficos y descripciones, en los cuales de una cantidad de expedientes analizados y examinados logre obtener un porcentaje de dichos expedientes, para así llegar a una conclusión según en sentencias dictadas por el Juez de ese tribunal antes mencionado, como se impuso la cantidad a pagar, si es que se impuso y en cuanto a la reparación del daño si se determinó pagar el daño moral, material o si se determinaron ambos. 
Núm. 26

ISSN: 2007-8870

\section{http://revistainvestigacionacademicasinfrontera.com}

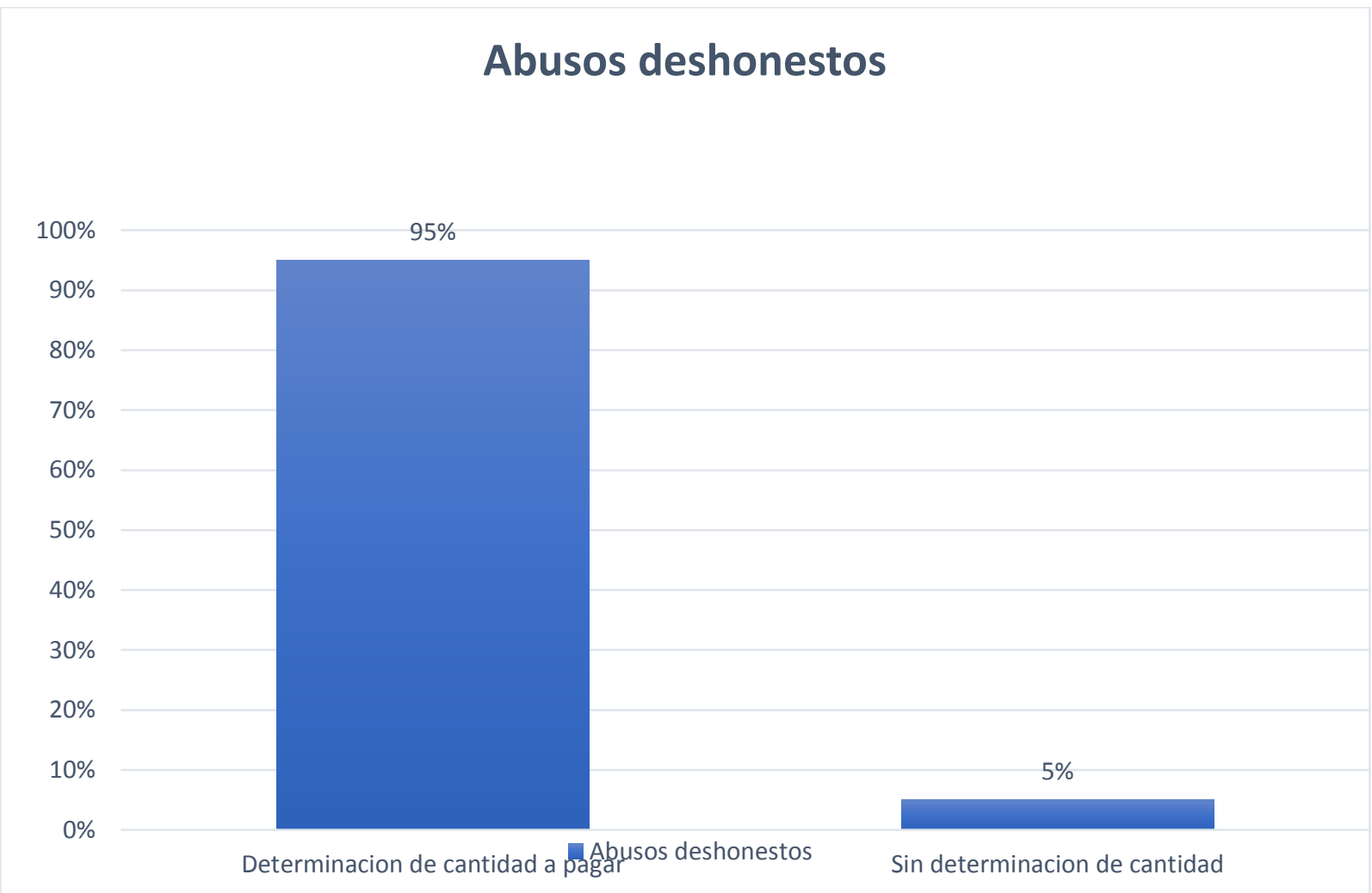

Gráfico 12. En el presente gráfico, analizo el delito de abusos deshonestos por lo que al sondear los expedientes en cuanto a este delito y su reparación del daño dictada en sentencia se determina que en un $95 \%$ de los expedientes analizados se les determino la cantidad a pagar a la víctima, mientras que en un 5\% de los expedientes se dejaron a salvo los derechos y no determino cantidad a pagar. 
Núm. 26

ISSN: 2007-8870

\section{http://revistainvestigacionacademicasinfrontera.com}

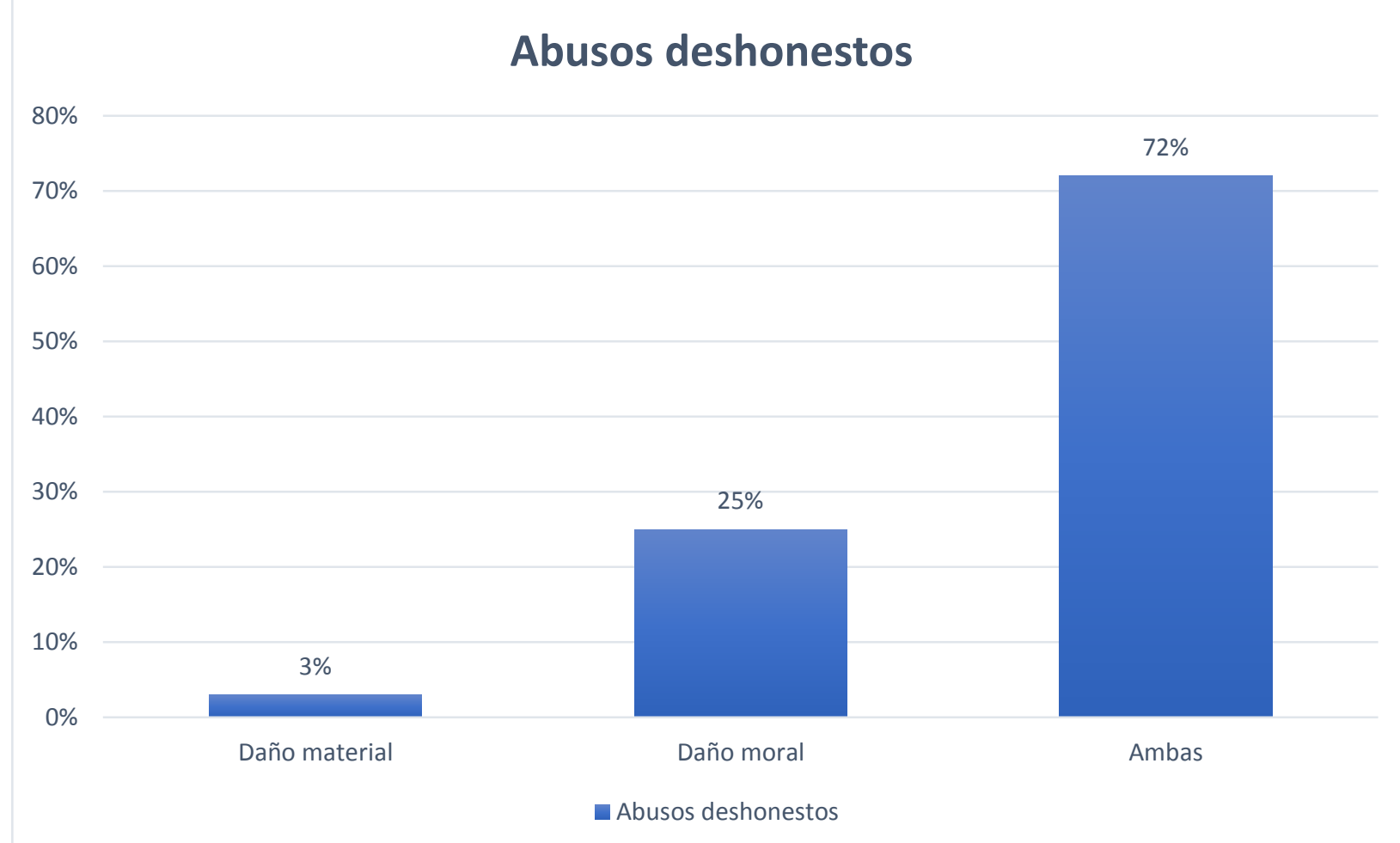

Gráfico 13. En el presente y ultimo gráfico, notamos que, en cuanto al delito de abusos deshonestos, se impuso la medida de reparación del daño moral y material en un $72 \%$ de los expedientes analizados en cuanto a ese delito, un $18 \%$ solo se le impuso la reparación del daño moral y en un $3 \%$ se impuso solo el daño material. Por lo que nos demuestra que en este delito que se le imponga como medida reparar el daño material y moral es muy común.

El análisis anterior fue sustentado en información obtenida de los expedientes del año 2015, del Juzgado de Primera Instancia Especializado en Justicia para Adolescentes, del Distrito Judicial de Cajeme, en Cócorit, Sonora. 
Julio- Diciembre 2017)

Año 10.

Revista de Investigación

Núm. 26

Académica sin Frontera

ISSN: 2007-8870

\section{http://revistainvestigacionacademicasinfrontera.com}

\section{CONCLUSIÓN}

En delitos graves como homicidio, violación y abusos deshonestos la victima queda muy dañada y atemorizada, por lo que es común que no quieran asistir a diligencias en el Juzgado, porque no quieren ni siquiera volver a ver al adolescente inculpado, en el delito de robo es de lo más común que la víctima exija le regresen lo que le robaron, ya que en la mayoría de los casos los policías recuperan el bien despojado.

En cuanto a la referida reparación del daño de las sentencias analizadas se desprende, que es común que a la víctima busque se le compense una parte si no es que totalmente el daño causado al momento de la comisión de la conducta desplegada por un adolescente en conflicto con la Ley, en todos los casos hay un daño material, moral o ambos, en algunos casos la víctima es aislada o no se le da la importancia que debería de proporcionársele, la atención se centra en el adolescente imputado, en algunos casos es muy fuerte el daño psicológico o físico que causa un adolescente al cometer el ilícito, la mayoría de ellos llevan a cabo el hecho bajo los efectos de algún tipo de droga, lo que con lleva que no están en sus cinco sentidos, y pueden actuar de manera agresiva o lesionar gravemente a su víctima.

A manera de propuesta: que el sistema de justicia para adolescentes funcione y no genere impunidad planteando la necesidad de que se establezca la necesidad de garantizar el pago de la reparación del daño desde el inicio de la carpeta de investigación obligando subsidiariamente sobre los que ejerzan la patria potestad o en consecuencia establecer mecanismos en donde el menor pueda garantizar el daño dado el aumento de conductas antijurídicas tipificadas como delitos en las que intervienen menores de edad entendiendo 


\section{http://revistainvestigacionacademicasinfrontera.com}

por estas no solo las faltas menores sino inclusive de las consideradas en el sistema de adultos como delitos graves.

\section{BIBLIOGRAFÍA}

- Bernardino Esparza Martínez, La Reparación del Daño, INACIPE, México.

- Código Nacional de Procedimientos Penales.

- Código Penal del Estado de Sonora

- Constitución Política de los Estados Unidos Mexicanos

- Díaz Cortés Lina Mariola. Derecho penal de menores. Bogotá. Un estudio comparado del derecho penal juvenil en Colombia y en España. Editorial Temis., p.32. 2009.

- Expediente, Archivo, del Juzgado Especializado en Justicia para Adolescentes, Cocorit, Sonora.

- Ley 252. Que establece el sistema integral de justicia para adolescentes del Estado de Sonora.

- Ley General de los Niños, Niñas y Adolescentes.

- Ley General de Victimas

- Maciá Gómez, R. 2010, “La dualidad del daño patrimonial y del daño moral”, Revista Asociación Española de Abogados Especializados en Responsabilidad Civil y Seguro, Núm. 36.

- Mazeaud, Jean, Henri y León, Lecciones de derecho civil. la responsabilidad civil, los cuasicontratos, trad. de Luis Alcalá-Zamora y Castillo, Buenos Aires, Ediciones Jurídicas Europa-América, 1960, vol. II, parte 2a., pp. 56 y 68.

- Morineau Iduarte, Martha e Iglesias González, Román, Derecho romano, Harla, México, 1987. 
Año 10.

Revista de Investigación

Núm. 26

Académica sin Frontera

ISSN: 2007-8870

\section{http://revistainvestigacionacademicasinfrontera.com}

- Suprema Corte de Justicia de la Nación, Protocolo de actuación para quienes imparten justicia en casos que involucren niñas, niños y adolescentes. México, 2014.

- Zannoni, “El daño en la responsabilidad civil”, Astrea, Buenos Aires, 1982. 